\title{
GREEDY STATE? THE EFFECT OF THE GOVERNMENT SHAREHOLDER ON THE DIVIDEND PAYOUT RATIO AND SMOOTHING LEVELS
}

\author{
Sabina Nowak*, Magdalena Mosionek-Schweda**, \\ Urszula Mrzygłód***, Jakub Kwiatkowski****
}

\begin{abstract}
Background. This study examines the dividend patterns among companies listed on the stock exchanges in selected countries from Europe, the Middle East, and Africa (EMEA), namely the Czech Republic, Egypt, Greece, Hungary, Poland, Qatar, the Russian Federation, South Africa, Turkey, and the United Arab Emirates.

Research aims. Although the dividend policy has been examined in numerous empirical studies, this paper aims to address the differences in the dividend payout ratios between the companies with- and without state ownership with respect to agency theory and the shareholders' structure. Moreover, the smoothing pattern of dividends is investigated from the perspective of the government presence in the ownership structure.
\end{abstract}

Methodology. The research procedure comprises the ordinary least squares estimation of two separate dividend smoothing equations and the use of adequate parametric or non-parametric statistical tests.

Key findings. The obtained results indicate that the presence of the state in the shareholders' structure coexists with the high levels of dividend payout ratios. The analysis of dividend smoothing behaviour gives mixed results. Although many companies smooth dividends in the research sample, the mean levels of the dividend speed of adjustment (SOA coefficients) are rather high among the stock markets in the selected EMEA countries. However, the country smoothing levels differ depending on the version of the applied equation. Moreover, no significant differences are found in the SOA levels between the companies with- and without state ownership.

\footnotetext{
* University of Gdańsk. E-mail: sabina.nowak@ug.edu.pl

*** University of Gdańsk. E-mail: magdams@ug.edu.pl

**** University of Gdańsk. E-mail: u.mrzyglod@ug.edu.pl

****k University of Gdańsk. E-mail: j.kwiatkowski@ug.edu.pl
} 
Key words: dividend smoothing, payout ratio, government shareholder, emerging stock markets, Europe, the Middle East, and Africa

\section{INTRODUCTION AND BACKGROUND}

Dividend policy is one of the crucial problems of business entities. The decision to distribute part of the attained profits among shareholders not only lowers the available cash flow but also influences the market valuation. Indeed companies operate within a given economical, institutional, and political framework and compete for external funds and those with a more attractive dividend policy are more desired by stock market investors (Ho, 2003).

Managers can choose among different types of dividend policies, which can be described in terms of their consistency. The current dividend not only can affect the current price of equity but also fosters future expectations towards dividend payouts. More importantly, as Lintner (1956) argues, managers avoid changes in dividends that cannot be maintained in future periods. Therefore, managers' attitude towards dividends implies the existence of dividend smoothing relative to earnings, which is described as the gradual adjustment of dividends towards the long-run target payout ratio (TPR) (Lintner, 1956).

The effect of ownership structure on the companies' dividend policy and dividend smoothing has been evaluated in many studies, both theoretical and empirical. One of the first seminal analyses was conducted by Jensen \& Meckling (1976), who redefined the definition of agency cost. According to their study, the efficiency of any activity in a company can be lowered by the different aims of the 'principal' and the 'agent' working on his behalf. Assuming that both of them act to maximise their own (not the company's) profit, agency costs may occur.

In terms of dividend policy, following the same logic, the payout can be determined by the opposite goals of shareholders (principals), who tend to maximise their earnings, and managers (agents), who maximise the company's value. La Porta, Lopez-de-Silanes, Shleifer, \& Vishny (2000) and Obradovich \& Gill (2013) suggested that managers prefer freezing the company's profits for their own purposes or spending them on (not always profitable) investment projects rather than on dividend payouts. At this point, agency models are not in line 
with Miller \& Modigliani's (1961) theory that dividend payout is the difference between the company's profits and its investments.

In their seminal work, Shleifer \& Vishny (1997) analysed the relation between ownership concentration and the agency problem. The authors claimed that companies should find an optimal relation between the concentration of power (i.e., minimise agency costs) and the minority shareholder protection. Furthermore, the authors raised the question of whether political and economic forces could drive corporate governance towards greater efficiency or the opposite. Similarly, La Porta et al. (2000) claimed that companies with greater minority shareholder protection pay higher dividends on average. Short, Zhang, \& Keasey (2002) proved that dividend policy (i.e. the amount of dividends paid) is positively correlated with institutional policy. According to Al-Malkawi, Bhatti, \& Magableh (2014), poor shareholder protection and corporate governance may result in high dividend payments to build a reputation among investors.

Gugler (2003) attempted to answer Shleifer \& Vishny's (1997) question, mentioned above, by analysing the government effect on the ownership structure. The author suggested that state-owned companies face agency problems twice: 1) similarly to other companies, between managers and politicians accountable for the companies and 2) between politicians and the 'ultimate owners' of the company (i.e. citizens).

Several empirical studies have been conducted on the problem of dividend policy and agency problems. The strength and the direction of correlation differ from country to country (Obradovich \& Gill, 2013). This finding is in accordance with that of Marsh \& Merton (1987), who suggested that dividend policy could not be explained by a single theoretical concept. Gill (2013) concluded that the decision to pay dividends is a negative function of ownership concentration in the United States. Khan (2006) proved that in the case of the United Kingdom, ownership concentration is negatively related to dividends. Furthermore, the author suggested that the type of shareholder (e.g., its area of activity) matters positively to insurance companies and negatively for individuals.

Some studies analysed the effect of agency costs on dividend smoothing. According to Leary \& Michaely (2008; 2011), firms smooth dividends more if the potential of agency conflict is higher. Furthermore, companies with a higher share of institutional investors in the ownership structure follow a dividend smoothing pattern. Shinozaki \& Uchida 
(2014) analysed over 6,000 companies in 28 markets and generally confirmed agency theory but also suggested that the determinants of dividend smoothing might not be universal among countries. In their later paper, Shinozaki \& Uchida (2015), with a larger set of countries, confirmed that companies characterised by concentrated structures with corporate controlling shareholders smooth dividends more. However, they found no evidence that the other ownership structure variables (e.g., percentage ownership of mutual funds and banks) affects the dividend-smoothing behaviour.

Conversely, the results obtained by Javakhadze, Ferris, \& Sen (2014) regarding the sample of firms from 24 countries revealed that companies with a more concentrated ownership structure smooth their dividends less.

Gugler (2003) examined the problem even further. By investigating the case of Austria, he proved that state-owned companies smooth dividends more than bank- and foreign-owned companies and that family companies are the least reluctant to cut the dividend. His conclusions were confirmed by Michaely \& Roberts (2011), who suggested that companies with an extreme ownership concentration (low agency costs) pay higher dividends and smooth dividends less. The findings of both studies are consistent with the initial theory of Jensen \& Meckling (1976).

As majority of the studies focus on the effect of agency costs on the dividend policy of US and UK companies, several national case studies should be mentioned. Heydari, Razeghi, \& Sharifi (2015) revealed that companies listed on the Tehran Stock Exchange would pay a higher dividend on average if the institutional ownership was greater. Similar results were obtained by Al-Najjar (2009) for Jordan. Wang, Manry, \& Wandler (2011) proved that state-owned companies pay dividends more frequently than others, which is consistent with agency theory. In the case of Finland, Maury \& Pajuste (2002) found that the concentration of control negatively affects the amount of dividend. Jeong (2013) revealed that the concentration of ownership is an important factor determining the dividend policy of South Korean companies. Aivazian, Booth, \& Cleary (2003) compared companies from eight developing countries with firms from the United States and proved that companies from the former pay higher dividends on average and have more concentrated structures. Mitton (2004) confirmed the initial findings of Shleifer \& Vishny (1997) by analysing 365 companies from 19 countries. 


\section{EMEA Countries in the dividend smoothing research}

The smoothing pattern of dividends has attracted international financial economists who conducted research mostly on the highly developed stock markets. Developing economies, including the EMEA region, have gained attention recently because of the fast growth of their stock markets in terms of the number of companies, trade volume, and capitalisation. For instance Rangvid, Schmeling, \& Schrimpf (2014) stated that dividends are predictable in countries where a typical firm is relatively small and the institutional and corporate governance quality is low. International comparisons were based on the dataset of companies coming from 50 countries, including the Czech Republic, Greece, Hungary, Poland, the Russian Federation, South Africa, and Turkey in the period of 1973-2009. In terms of dividend smoothing, they revealed that in the countries where companies smooth dividends, predicting dividend growth is difficult because no connection exists between fluctuations in dividend yields and expected dividend growth.

An interesting comparative analysis of dividend policy of companies in the Russian Federation and Poland and those from the developed markets, namely France and Germany was conducted by Belousova, Gurianov, Melnichuk, Vinichenko, \& Duplij (2016). The percentage of companies paying dividends in 2003-2014 was comparable between the Russian Federation and Poland but was lower than those of Germany and France. Polish and Russian companies were generally not willing to smooth dividends unlike the German and French firms, which would rather keep their dividends at the same level and rarely cancel payments.

The dividend behaviour of Polish companies was also investigated by Gostkowska-Drzewicka \& Majerowska (2016), Kowerski \& Wypych (2016) and Kowalewski, Stetsyuk, \& Talavera (2007). Gostkowska-Drzewicka \& Majerowska (2016) analysed the construction companies quoted on the Warsaw Stock Exchange in the period of 2000-2014. Their findings confirmed the validity of Lintner's model for construction companies. Kowerski \& Wypych (2016) analysed 72 companies listed on both stock markets (regulated and alternative trading systems) managed by the Warsaw Stock Exchange that paid dividend regularly in the period of 2012-2016. The authors confirmed that the companies controlled by strategic investors have a higher dividend payout ratio than those owned by institutional investors. Kowalewski et al. (2007) 
focused on the connection between corporate governance practices and dividend policy. They analysed selected companies listed on the Polish stock market (110 non-financial entities in the period of 1998-2004) and revealed that the dividend-paying companies had higher corporate governance practice in comparison to the non-dividend-paying firms. A similar research on Russian companies was conducted by Berezinets, Ilina, \& Alekseeva (2014) and Belomyttseva \& Grinkevich (2017). Berezinets et al. (2014) investigated the effect of ownership's structure on the dividend policy analysing whether foreign owners, offshore companies, the state, Russian non-financial companies, financial institutions, and insiders with a share in a company's capital have different effects on dividend payments. The authors selected companies with a dual-class share structure listed on the Russian Training System (RTS) stock exchange for the period of 2003-2009. Belomyttseva \& Grinkevich (2017) focused on state ownership in the shareholder structure of large Russian corporations and found that this factor was the most important in determining the dividend decisions of companies in the Russian Federation.

Al-Ajmi (2010) examined the dividend policy of banks listed on the stock exchanges of Gulf Cooperation Council countries: Bahrain, Kuwait, Oman, Saudi Arabia, Qatar, and the UAE (the last two countries are also the objects of our analysis). Their results indicated that in all the investigated markets except Qatar, the banks' dividend policy was well explained by Lintner's model. The dividend policy of the banks was also explored by Hassan, Farhat, \& Al-Zubi (2003). The authors analysed the Islamic banks located in Egypt, Turkey, and the UAE. According to their findings, Islamic banks follow a stable dividend policy determined primarily by earnings. Ibrahim (2016) examined the dividend performance of banks based in the UAE. The author analysed the dividend behaviour of eight banks in the period of 2001-2005. The results revealed that the dividend policy of the analysed banks was affected by several factors, such as profitability level, uncertainty, bank growth, and earnings stability. The analysis also showed that most of the banks maintained a good level of dividend payments from their earnings.

Studies on Turkish companies and their dividend policy have been conducted by Al-Najjar \& Kilincarslan (2017) and Adaoglu (2000), among others. Both authors examined the companies listed on the Istanbul Stock Exchange (ISE). According to Al-Najjar \& Kilincarslan 
(2017), the ISE firms have long-term payout ratios and adjust cash dividends through a moderate level of smoothing, and thus they adopt stable dividend policies. Additionally, the author found that the ownership's structure affects dividend smoothing on the Turkish market and that the more profitable, the more mature and the larger the companies are, the more willing they are to pay dividends than firms with higher investment opportunities and more debt. Unlike the results of Al-Najjar \& Kilincarslan (2017) that supported the stable dividend policy behaviour of the ISE corporations, the findings obtained by Adaoglu (2000) showed that the ISE companies follow unstable cash dividend policies and that earnings are the main factor determining the amount of dividend payments.

El-Ansary \& Gomaa (2012) analysed the relation between the ownership structure and the dividend policy of Egyptian companies. Their research comprised data for 100 companies included in the EGX100 (i.e., the Egyptian Stock Exchange index for large, medium, and small companies) and listed on the EGX in the period of 2005-2010. Their findings indicated that ownership structure has no effect on dividend policy except public companies and private holdings, which have a positive and significant effect. Moreover, the authors found that profitability has a significant positive effect on dividend decisions; i.e., the higher the profitability of the company is, the higher the dividend payments. A similar research was conducted for the Czech Republic market by Bena \& Hanousek (2008). The authors analysed the companies listed on the Prague Stock Exchange in the period of 1996-2003 and divided them into three categories: majority ownership (more than $50 \%$ of shares), blocking minority ownership (more than $33.3 \%$, but not more than 50\%) and legal minority ownership (at least $10 \%$, but not more than $33.3 \%$ ). Their findings confirmed that corporate dividend policy in the Czech Republic depends on the concentration and domicile of ownership. Companies with a dominant majority owner pay dividends less often, and their TPR is small. Conversely, companies with a majority owner and at least one strong minority owner distribute dividends more often, and their TPR is large. This dividend behaviour was observed in large domestic and foreign owners.

Eriotis \& Vasiliou (2011) and Eriotis, Vasilou, \& Zisis (2007) explored the corporate dividend policy in the Greek market. The results of Eriotis \& Vasiliou's (2011) study confirmed the relevance of past dividends and company performance in explaining corporate dividends. 
This research included a sample of 149 Greek companies quoted on the Athens Stock Exchange in the period of 1996-2001. Eriotis et al. (2007) reduced their study sample to banks and argued that volatility of earnings is higher for banks than for other industrial companies because of accounting practice-related reasons. The results showed that no connection exists between last year's dividends and the current period's dividends after controlling for earnings in the case of banks. This finding is due to high earnings fluctuations and bank managers not adhering to a long-term dividend policy unaffected by the level of bank performance.

\section{Study objectives and research questions}

In the last few decades, the researchers have tried to solve the dividend 'puzzle' and dividend smoothing phenomenon. One of the most prominent theoretical explanations lays in agency theory discussed above. However, the importance of agency theory is at times questioned, especially in the analyses devoted to emerging markets. Therefore, we decided to contribute to the existing literature on that issue.

Furthermore, in the study we focus on the distinction between the companies with- and without the government shareholder in the ownership's structure, since - to the best of our knowledge - the impact of the government shareholder on the company's dividend policy has not been comprehensively discussed on the emerging markets.

On the basis of an extensive dataset of companies listed on the selected stock exchanges in 10 emerging economies from Europe, the Middle East, and Africa (EMEA), we aim to answer three research questions. First, we refer to agency theory and shareholders' structure to examine the differences in dividend payout ratios between companies with- and without the government shareholder. Second, we address the relationship between earnings and dividend payouts among companies listed on the selected EMEA stock markets. Third, we combine two above problems and examine the influence of a government shareholder on the dividend smoothing levels. The three research questions are as follows:

Question 1. Does the state ownership determine the dividend policy characterised by a higher payout ratio?

Question 2. Do managers of the companies listed on the selected emerging stock markets follow a dividend policy that can be characterised in terms of smoothing? 
Question 3. Does the state ownership determine higher levels of dividend smoothing?

In our study we employ a sample encompassing companies listed on the European stock exchanges, namely, those from the Czech Republic, Greece, Hungary, Poland, the Russian Federation, and Turkey, as well as companies from the Middle East and African stock markets, such as those from Egypt, the United Arab Emirates (UAE), Qatar, and South Africa. The broader EMEA region encompasses Europe, the Middle East, and Africa, including 116 countries in total. However we concentrate only on those countries that have managed to develop larger stock markets in the recent decades and which are recognised as emerging stock markets and included in the MSCI Emerging Stock Market Index. To the best of our knowledge, no studies have been conducted yet on the same group of countries that we selected for analysis.

All information on dividend payouts in the period of 1995-2015 was retrieved from the Thomson Reuters Eikon 4. This unique database includes all publicly traded companies on the world's stock markets.

The rest of the paper is organised as follows. Section 2 briefly describes the selected stock markets in terms of capitalisation and trading value, the data and research design are presented in section 3. The obtained results are discussed in section 4 . The conclusions are presented in the last section.

\section{EMEA STOCK MARKETS: GENERAL OVERVIEW}

The origin of most of the analysed stock exchanges dates back to the $19^{\text {th }}$ century, but all of them faced some period of closure due to political reasons. The only exceptions are the Athens Stock Exchange, which has operated continuously since it was established in 1876, and the Johannesburg Stock Exchange, which started its operation in 1887. Stock markets in Eastern Europe had been closed as the result of the World War II and reopened as a consequence of the transition to market economy. The Warsaw Stock Exchange in Poland was restored in 1991, and the Budapest Stock Exchange restarted its quotation in 1990 and the Prague Stock Exchange in 1993. The central planning and socialist policies adopted in Egypt were part of the reason for the Egyptian Exchange closure from 1961 to 1992. 
The Moscow Exchange has been operating in its current form since 2011 because of the merger of the RTS and the Moscow Interbank Currency Exchange. The Borsa Istanbul was formed in 2013 as a merger of the former Istanbul Stock Exchange, the Istanbul Gold Exchange, and the Derivatives Exchange of Turkey. The youngest stock exchanges, included in the analysed group of EMEA emerging markets, are the Qatar Exchange (established in 1995) and the Dubai Financial Market (formed in 2000).

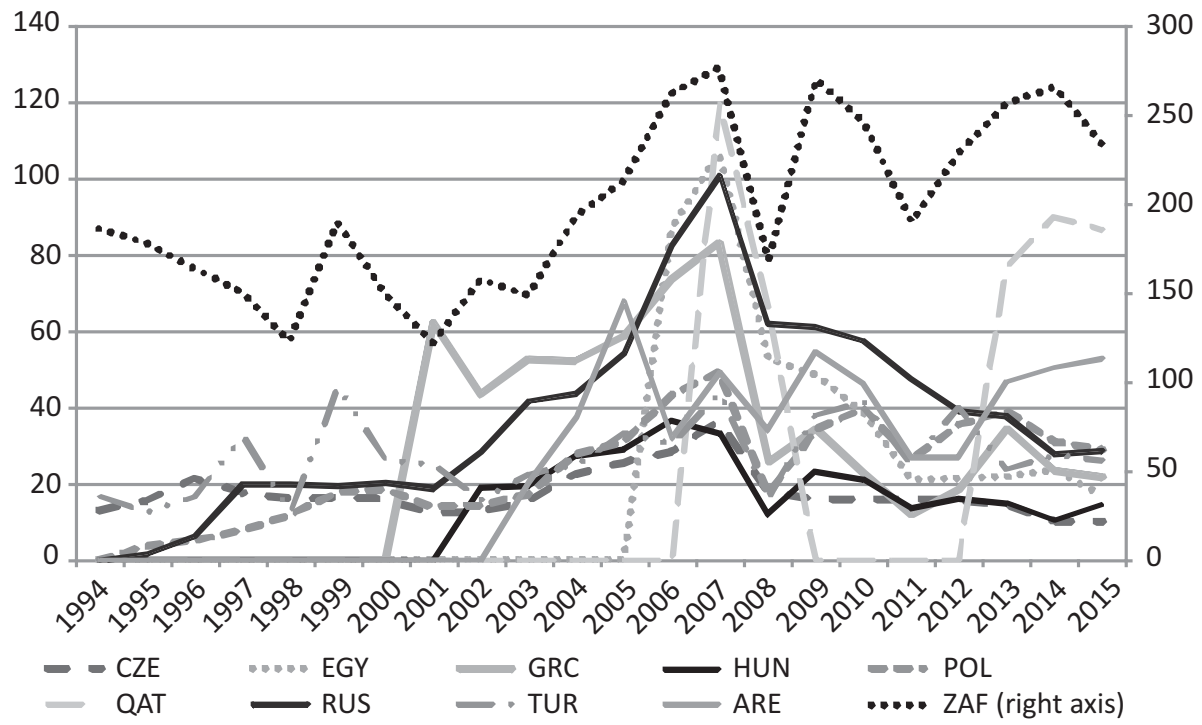

Figure 1. Market capitalisation of listed companies to GDP (in \%)

CZE - the Czech Republic, EGY - Egypt, GRC - Greece, HUN - Hungary, POL - Poland, QAT - Qatar, RUS - the Russian Federation, TUR - Turkey, ARE - the United Arab Emirates, ZAF - South Africa

Source: own work based on the WDI Database, 2017.

The analysed exchanges vary significantly in terms of size and liquidity. Considering the number of listed companies at the end of 2015, the largest stock market is that of Poland with 487 listed companies, followed by Borsa Istanbul with 393. The rest of the stock markets are listed as follows in decreasing order: the Johannesburg Stock Exchange with 382 companies, the Moscow Exchange with 254 companies, the Egyptian Exchange with 252 companies, and the Athens Stock Exchange with 240. The number of issuers quoted on the other exchanges is in the range of 40-70. 
Given the capitalisation criterion in gross domestic product (GDP) terms, the highest level of the indicator throughout the analysed period is attained by the Johannesburg Stock Exchange. This indicator has high volatility, but since 2006 , it has exceeded $200 \%$ every year (Figure 1). It is worth noting than in the examined stock markets, except the Johannesburg Stock Exchange, the highest capitalisation to GDP rate occurred in 2007. By 2015, none of the stock exchanges had reached the 2007 value of this indicator. The international financial crisis that had begun in 2008 also affected the analysed stock markets.

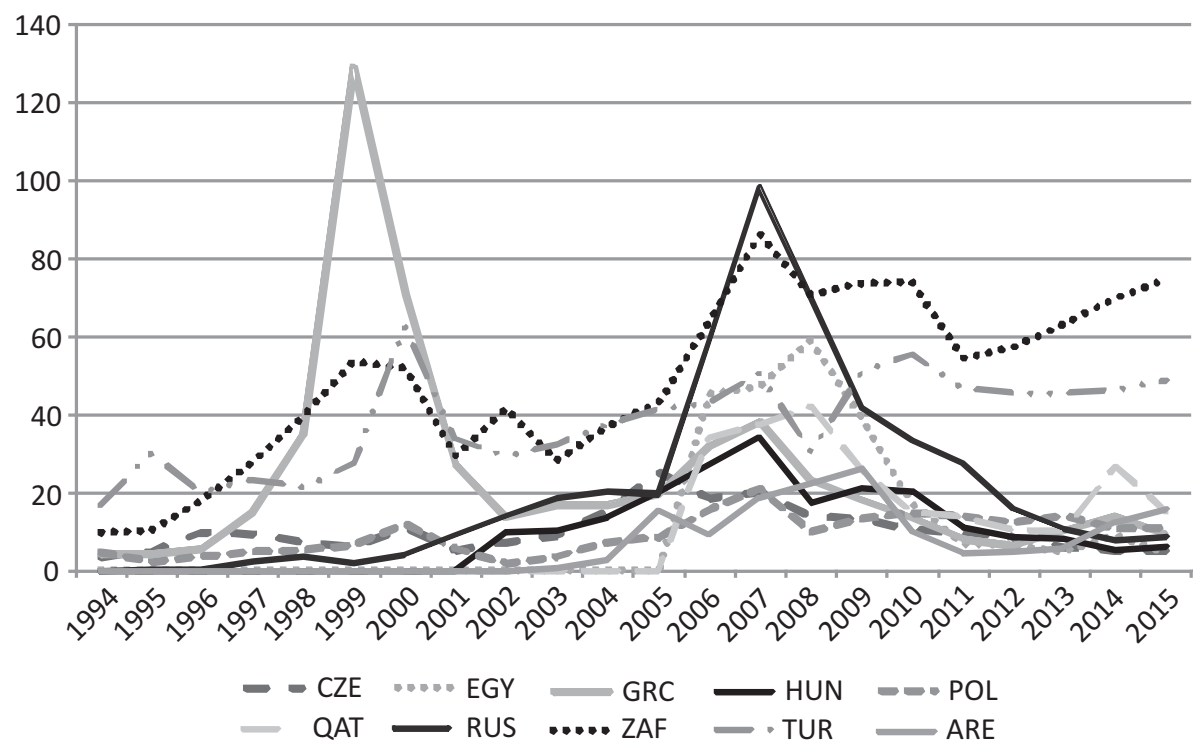

Figure 2. Stocks traded, total value (\% of GDP)

CZE - the Czech Republic, EGY - Egypt, GRC - Greece, HUN - Hungary, POL - Poland, QAT - Qatar, RUS - the Russian Federation, TUR - Turkey, ARE - the United Arab Emirates, ZAF - South Africa

Source: own work based on the WDI Database, 2017.

In consideration of the market liquidity measured by the value of traded stocks to the GDP, great differences were observed in the analysed countries. However, the Johannesburg Stock Exchange ranks first, with its ratio increasing from $9.56 \%$ in 1994 to $74.38 \%$ in 2015 . The lowest values of this indicator were observed in the Czech Republic, Egypt, Greece, Hungary, and the Russian Federation. These stock markets did not exceed 10\% in 2015 (Figure 2). In conclusion, the most developed stock market in terms of quoted companies, capitalisation, and liquidity 
is the Johannesburg Stock Exchange in South Africa, whereas the least developed one is the stock exchange in the Czech Republic.

\section{DATA AND METHODOLOGY}

The initial sample comprised 2,481 companies listed on the stock exchanges of 10 emerging countries from the EMEA, namely, the Czech Republic, Egypt, Greece, Hungary, Poland, Qatar, the Russian Federation, South Africa, Turkey, and the UAE, in the period of 1994-2015. The size of the research sample was gradually reduced. First, we excluded all financial companies from the sample. Second, we omitted the non-financial and non-insurance companies that had paid cash dividends for less than six consecutive years in the analysed period. Third, we excluded either the observations with non-positive earnings per share ratio or those with dividends per share equal to zero. Fourth, we maintained in the sample countries with at least five companies that fulfilled the above-mentioned requirements. The last criterion excluded the Czech Republic from the sample. Eventually, the sample comprised 371 companies, with 86 companies having the government in their ownership's structure and 285 companies without the state among their shareholders. The identification of the government presence in the shareholders' structure was conducted on the basis of Thomson Reuters Eikon 4 data.

To answer the first research question, we computed the main statistical characteristics of the dividend payout ratios in two subsamples: with the government as a shareholder (GOV) and without the government (NGOV). As the assumption of the normal distribution of the median payout ratio was not satisfied, we used the non-parametric Mann-Whitney U-test which assumes that two groups (subsamples) come from the same population The null hypothesis of the Mann-Whitney U-test assumes the equality of the distributions of the two subsamples, whereas the alternative assumes the differences in medians.

To answer the second and third research questions, we introduced two different approaches to calculate the speed of adjustment (SOA) coefficients. The first approach was based on the partial-adjustment model of dividend payout proposed by Lintner (1956). We used the widely acknowledged specification suggested by Fama \& Babiak (1968):

$$
\Delta D_{i t}=\alpha_{i}+\gamma_{1 i} D_{i, t-1}+\gamma_{2 i} E_{i t}+u_{i t}
$$


where $D_{i t}$ is the target level of dividends for firm i in year t, $E_{i t}$ is firm i's earnings per share in year t, $\gamma_{1 i}, \gamma_{2 i}$ are parameters and $u_{i t}$ is the error term. To estimate the parameters of Equation (1), we used the ordinary least squares (OLS) method. The SOA coefficient was estimated as $-\hat{\gamma}_{1 i}$. To control for the scale effects, we divided the dividends and earnings by the number of common shares outstanding (Fama, \& Babiak, 1968; Brav, Graham, Harvey, \& Michaely, 2005).

The second approach was based on the two-step procedure proposed by Larkin, Leary, \& Michaely (2016). In the first step, we estimated the TPR for each company as its median payout ratio over the period analysed (the payout ratio was calculated as the common dividends divided by net income). In turn, we computed a deviation from the estimated TPR for each company:

$$
d e v_{i t}=T P R_{i t} E_{i t}-D_{i, t-1}
$$

In the second step, we estimated the SOA coefficient as a parameter $\hat{\beta}_{i}$ from the regression:

$$
D_{i t}={ }_{i}+{ }_{i} d e v_{i t}+u_{i t}
$$

We also used the OLS method to estimate the parameters of Equations (2) and (3).

The obtained results were checked for statistical significance. To test for the differences among countries and the differences between either subsamples (GOV vs. NGOV) or the estimation approaches (Lintner's model vs. Larkin, Leary, \& Michaely's two-step procedure), the parametric test for the difference in means or the non-parametric tests were employed. For the latter case, the median test and the Kruskal-Wallis rank test were used. The null hypothesis of the median test claims that two (or more) populations have identical medians on some variable, whereas the alternative hypothesis says that at least one median is different. The null hypothesis of the Kruskal-Wallis rank test assumes that there is no difference in distribution between two (or more) independent populations (in other words: the centres of the distribution for all the populations are equal to each other). The alternative hypothesis says that at least one of the populations has a different measure of the centre than the others. 


\section{RESULTS AND DISCUSSION}

The identification of companies with a government shareholder determines the differences in the levels of dividend payout ratios between two separate groups of companies: those with (GOV) and those without (NGOV) government presence in the shareholders' structure.

Given the median levels in the subsequent years (Figure 3), companies from the GOV subsample had higher payout ratios than the NGOV subsample. Companies with state ownership experienced a low level of payout ratios on average only in 1996, 1999, and 2000. From 2007 and 2011, the median payout ratios in the GOV subsample were higher than those in other years. Nevertheless, we can safely say that companies with state ownership paid higher dividends on average in terms of profit during the international financial crisis.

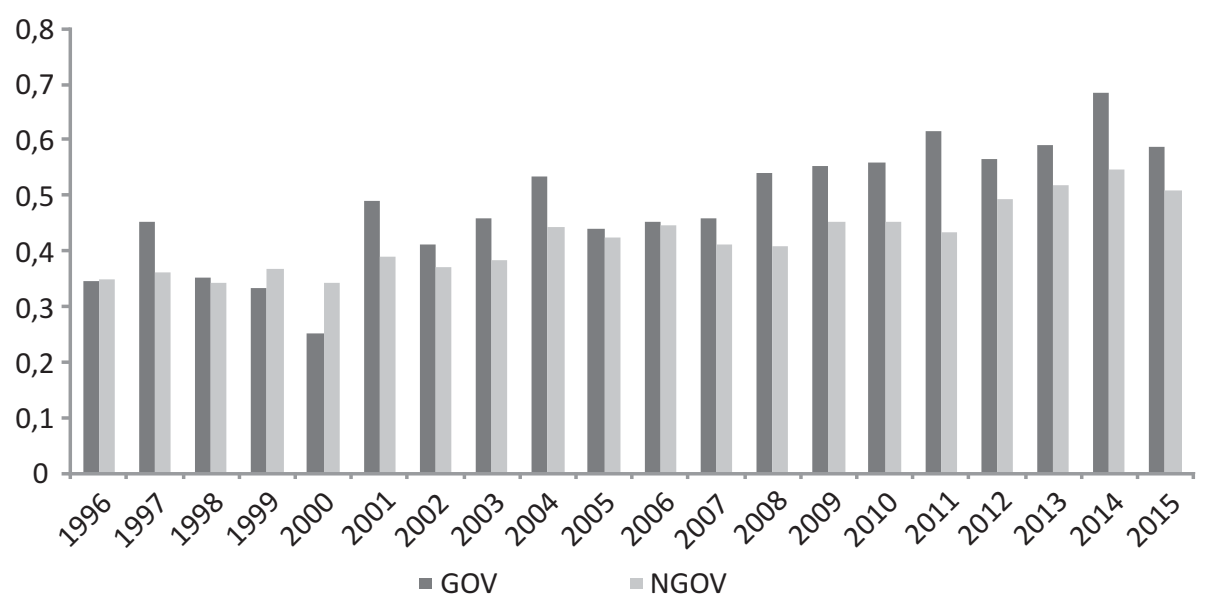

Figure 3. Median payout ratio among companies with (GOV) and without (NGOV) government in the shareholder structure

Source: own work.

Table 1 summarises the descriptive statistics of the dividend payout ratio computed for the entire sample of companies and with respect to the shareholders' differences. The mean value of the dividend payout ratio for all the companies in the analysed period of 1994-2015 is equal to 0.4986 , and the mean payout ratio for the GOV subsample is higher (0.5410). The variability of the dividend payout ratio, reflected by the coefficient of variation, is higher for the NGOV subsample. Moreover, 
with the exception of the GOV subsample, the variable is not normally distributed.

Table 1. Main characteristics of the dividend payout ratio

\begin{tabular}{|l|r|c|c|c|c|c|c|c|c|c|}
\hline & N & Mean & $\begin{array}{c}\text { Medi- } \\
\text { an }\end{array}$ & Min & Max & $\begin{array}{c}\text { Std. } \\
\text { dev. }\end{array}$ & Skew. & $\begin{array}{c}\text { Kurto- } \\
\text { sis }\end{array}$ & $\begin{array}{c}\text { JB } \\
\text { stat. }\end{array}$ & $\begin{array}{c}\text { p-val- } \\
\text { ue }\end{array}$ \\
\hline ALL & 371 & 0.4986 & 0.4587 & 0.0774 & 2.9000 & 0.2656 & 2.4344 & 17.2800 & $4,982.09$ & 0.0000 \\
\hline GOV & 86 & 0.5410 & 0.5486 & 0.1046 & 0.9337 & 0.2239 & -0.2407 & -0.8299 & 3.2982 & 0.1922 \\
\hline NGOV & 285 & 0.4858 & 0.4300 & 0.0774 & 2.9000 & 0.2761 & 2.9122 & 19.9110 & $5,110.54$ & 0.0000 \\
\hline
\end{tabular}

JB stat. - the Jarque'a-Bera test statistic under relevant null hypothesis is distributed as $\chi^{2}$ with 2 degrees of freedom

Source: own work with Statistica 13.

The results of the JB test did not allow for the use of parametric tests to obtain the difference in the mean values of the payout ratio. Thus, the Mann-Whitney U-test was employed. Given the value of the $\mathrm{Z}$ statistics (3.7413) with the corresponding $\mathrm{p}$-value (0.0030) at the 5\% significance level, we rejected the null hypothesis that distributions of the median payout ratios are equal for companies with- and without government in ownership's structure. The median payout ratio for GOV companies is significantly higher than that in the NGOV companies. Overall, the companies with state in the ownership's structure pay higher dividends relative to earnings.

We limited the sample size after computing the SOA coefficients using the two approaches mentioned above. We excluded both the outliers (SOA values higher than 2) and the SOAs with a negative sign. For the SOA analysis, we considered the sample of 351 companies, including 53 from Egypt, 53 from Greece, 6 from Hungary, 52 from Poland, 12 from Qatar, 28 from the Russian Republic, 91 from South Africa, 51 from Turkey, and 5 from the UAE. As previously mentioned, the Czech Republic representatives were left out of the final sample.

Table 2 summarises the descriptive statistics for Lintner's approach. The mean values of the SOA of the dividend coefficient range from 0.6533 for the UAE to 0.9634 for Poland. The estimated values of the SOA are normally distributed according to the JB statistics in all the distinguished subsamples and for the entire research sample. The obtained levels of the results remain high. Therefore, given that 
dividend smoothing is inversely related to the SOA coefficient level, the results obtained from the first empirical approach suggest a low level of smoothing in all selected countries.

Table 3 presents the results of Larkin, Leary, \& Michaely's two-step estimation procedure. The mean values of the SOA coefficient range from 0.5634 for the UAE to 0.8541 for Hungary. Comparing the results summarised in Tables 2 and 3, the mean values of the SOA coefficients calculated for each country, except Hungary, are lower in the case of the second empirical approach.

Given the ownership structure, the mean values of the SOA for Lintner's approach (Table 2) seem to be similar in both subsamples (GOV and NGOV). Conversely, in Larkin, Leary, \& Michaely's twostep estimation procedure (Table 3), the mean SOA coefficient in the GOV subsample is 0.7617 and that in the NGOV subsample is lower at 0.6853 . Overall, the companies with state ownership show a faster adjustment of dividends.

Table 2. Main characteristics of the SOA coefficient calculated on the basis of Lintner's partial adjustment model (1956)

\begin{tabular}{|l|r|r|r|r|r|c|c|c|c|c|}
\hline \multirow{2}{*}{$\begin{array}{c}\text { Sam- } \\
\text { ple }\end{array}$} & \multirow{2}{*}{$\mathbf{N}$} & \multicolumn{9}{|c|}{ Statistic } \\
\cline { 5 - 11 } & & Mean & Median & Min & Max & $\begin{array}{c}\text { Std. } \\
\text { dev. }\end{array}$ & Skew. & $\begin{array}{c}\text { Kurto- } \\
\text { sis }\end{array}$ & $\begin{array}{c}\text { JB } \\
\text { stat. }\end{array}$ & $\begin{array}{c}\text { p-val- } \\
\text { ue }\end{array}$ \\
\hline All & 351 & 0.8280 & 0.8363 & 0.0160 & 1.9989 & 0.3857 & 0.1150 & -0.1543 & 1.1217 & 0.5707 \\
\hline GO & 82 & 0.8378 & 0.8428 & 0.0973 & 1.6661 & 0.3684 & 0.1064 & -0.2571 & 0.3806 & 0.8267 \\
\hline NGO & 269 & 0.8250 & 0.8346 & 0.0160 & 1.9988 & 0.3914 & 0.1198 & -0.1389 & 0.8601 & 0.6505 \\
\hline Egypt & 53 & 0.8559 & 0.8753 & 0.0523 & 1.6327 & 0.3597 & -0.0394 & -0.0064 & 0.0138 & 0.9931 \\
\hline Greece & 53 & 0.8341 & 0.8637 & 0.0973 & 1.8311 & 0.4102 & 0.1178 & -0.4976 & 0.6695 & 0.7155 \\
\hline Hungary & 6 & 0.8168 & 0.8305 & 0.5077 & 1.0681 & 0.1971 & -0.3467 & -0.8565 & 0.3036 & 0.8592 \\
\hline Poland & 52 & 0.9634 & 0.9698 & 0.0261 & 1.9988 & 0.4922 & -0.0873 & -0.6095 & 0.8711 & 0.6469 \\
\hline Qatar & 12 & 0.7537 & 0.7734 & 0.0203 & 1.4568 & 0.3835 & -0.0852 & -0.2667 & 0.0501 & 0.9735 \\
\hline Russia & 28 & 0.7695 & 0.8245 & 0.1258 & 1.3423 & 0.3113 & -0.3657 & -0.4680 & 0.8798 & 0.6441 \\
\hline $\begin{array}{l}\text { South } \\
\text { Africa }\end{array}$ & 91 & 0.7135 & 0.7258 & 0.0476 & 1.3189 & 0.3139 & -0.1153 & -0.7414 & 2.2857 & 0.3189 \\
\hline Turkey & 51 & 0.9261 & 0.9312 & 0.0160 & 1.7431 & 0.3781 & -0.1716 & -0.1731 & 0.3139 & 0.8547 \\
\hline UAE & 5 & 0.6533 & 0.5738 & 0.0923 & 1.2578 & 0.4405 & 0.1592 & -1.0357 & 0.2446 & 0.8849 \\
\hline
\end{tabular}

Source: own calculations with Gretl and Statistica 13. 
Table 3. Main characteristics of the SOA coefficient calculated according to Larkin, Leary \& Michaely's (2016) approach

\begin{tabular}{|l|r|r|r|c|c|c|c|c|c|c|}
\hline \multirow{2}{*}{ Sample } & \multirow{2}{*}{$\mathbf{N}$} & \multicolumn{7}{|c|}{ Statistic } \\
\cline { 4 - 11 } & & Mean & $\begin{array}{c}\text { Medi- } \\
\text { an }\end{array}$ & Min & Max & $\begin{array}{c}\text { Std. } \\
\text { dev. }\end{array}$ & Skew. & $\begin{array}{c}\text { Kurto- } \\
\text { sis }\end{array}$ & JB & $\begin{array}{c}\text { p-val- } \\
\text { ue }\end{array}$ \\
\hline All & 351 & 0.7031 & 0.7255 & 0.0004 & 1.8197 & 0.3368 & 0.1792 & -0.3262 & 3.4340 & 0.1796 \\
\hline GO & 82 & 0.7617 & 0.7835 & 0.0004 & 1.4525 & 0.3397 & 0.0812 & -0.5648 & 1.1802 & 0.5543 \\
\hline NGO & 269 & 0.6853 & 0.7167 & 0.0220 & 1.8197 & 0.3345 & 0.2083 & -0.2329 & 2.5523 & 0.2791 \\
\hline Egypt & 53 & 0.7551 & 0.7931 & 0.0704 & 1.4498 & 0.3144 & 0.1092 & -0.4393 & 0.5315 & 0.7666 \\
\hline Greece & 53 & 0.6218 & 0.6018 & 0.0742 & 1.5888 & 0.3428 & 0.5774 & 0.0199 & 2.9455 & 0.2293 \\
\hline Hungary & 6 & 0.8541 & 0.8547 & 0.6986 & 1.0505 & 0.1298 & 0.2773 & -1.0896 & 0.3737 & 0.8296 \\
\hline Poland & 52 & 0.7469 & 0.7415 & 0.0004 & 1.8197 & 0.4181 & 0.2316 & -0.6851 & 1.4817 & 0.4767 \\
\hline Qatar & 12 & 0.5634 & 0.5174 & 0.0704 & 0.9727 & 0.2906 & 0.1140 & -1.0022 & 0.5282 & 0.7679 \\
\hline Russia & 28 & 0.6861 & 0.7373 & 0.0220 & 1.1966 & 0.2986 & -0.2871 & -0.6467 & 0.8726 & 0.6464 \\
\hline $\begin{array}{l}\text { South } \\
\text { Africa }\end{array}$ & 91 & 0.6386 & 0.6590 & 0.0293 & 1.3440 & 0.3098 & 0.0288 & -0.7946 & 2.4066 & 0.3002 \\
\hline Turkey & 51 & 0.8395 & 0.8451 & 0.2559 & 1.3275 & 0.2626 & -0.2110 & -0.6408 & 1.2507 & 0.5351 \\
\hline UAE & 5 & 0.5919 & 0.4777 & 0.1113 & 1.7062 & 0.6473 & 1.2291 & -0.1019 & 1.2611 & 0.5323 \\
\hline
\end{tabular}

Source: own work with Gretl and Statistica 13.

The results of the JB test enabled the use of parametric tests to obtain the difference in the mean values of the SOA coefficients. The results indicate that, given the $5 \%$ significance level, both the variances and the mean values of the SOA are equal in the comparison of companies with and without state ownership in both Lintner's and Larkin, Leary, \& Michaely's approaches. By contrast, the means of the SOA computed for all companies $(\mathrm{N}=351)$ are not identical in both approaches: the mean value of the SOA is statistically significantly higher when calculated on the basis of Lintner's model than the one calculated using Larkin, Leary, \& Michaely's procedure. However, their variances are homogenous (Table 4).

The results of the median test conducted for companies with and without the government shareholder confirm the findings of the parametric test for the difference in means. As the value of the median test statistic is equal to 0.0794 (0.2852) with the corresponding p-value of 0.7781 (0.5933) for Lintner's (Larkin, Leary, \& Michaely's) approach at the $5 \%$ significance level we cannot reject the hypothesis that the 
median values of the SOA coefficient are equal between the GOV and NGOV companies in the entire sample $(\mathrm{N}=351)$.

Table 4. Results of the parametric test for the difference in means of the SOA coefficients

\begin{tabular}{|l|c|c|c|c|}
\hline \multicolumn{1}{|c|}{ Pair* } & $\begin{array}{c}\text { F stat. } \\
\text { Levene's }\end{array}$ & p-value & t stat. & p-value \\
\hline All (L)-all (LLM) & 2.6905 & 0.1014 & 4.5685 & 0.0000 \\
\hline GOV-NGOV (L) & 0.5024 & 0.4789 & 0.2635 & 0.7923 \\
\hline GOV-NGOV (LLM) & 0.0017 & 0.9675 & 1.8045 & 0.0720 \\
\hline
\end{tabular}

* (L) - SOA calculated on the basis of Lintner's partial adjustment model (1956), (LLM) - SOA calculated according to Larkin, Leary and Michaely's (2016) approach; all - all companies $(\mathrm{N}=351)$, GOV companies with the government shareholder $(\mathrm{N}=82)$, NGOV companies without the government shareholder $(\mathrm{N}=269)$

Source: own work with Statistica 13.

Interestingly, the findings of the median test and the Kruskal-Wallis rank test, conducted for the subsamples of the GOV and NGOV companies separately, lead to different conclusions.

Table 5. Results of the median test and the Kruskal-Wallis test for the SOA coefficient among EMEA countries - GOV vs. NGOV comparison

\begin{tabular}{|l|l|l|l|l|l|l|l|l|}
\hline Sample & \multicolumn{4}{|c|}{ GOV** } & \multicolumn{4}{c|}{ NGOV** } \\
\hline Method** & $\begin{array}{l}\text { Median } \\
\text { test } \\
\text { statistic }\end{array}$ & p-value & $\begin{array}{l}\text { K-W test } \\
\text { statistic }\end{array}$ & p-value & $\begin{array}{l}\text { Median } \\
\text { test } \\
\text { statistic }\end{array}$ & p-value & $\begin{array}{l}\text { K-W test } \\
\text { statistic }\end{array}$ & p-value \\
\hline L & 5.8022 & 0.5630 & 6.8397 & 0.4458 & 14.8565 & 0.0620 & 18.3985 & 0.0184 \\
\hline LLM & 5.8306 & 0.5597 & 9.2453 & 0.2355 & 16.7581 & 0.0327 & 20.3846 & 0.0090 \\
\hline
\end{tabular}

* L - SOA calculated on the basis of Lintner's model, LLM - SOA calculated according to Larkin, Leary \& Michaely's (2016) approach; the median test and the Kruskal-Wallis test statistics under the relevant null hypotheses are both distributed as $X^{2}$ with the number of degrees of freedom equal to $8 ; * * \mathrm{GOV}$ - companies with the government shareholder $(\mathrm{N}=82)$, NGOV - companies without the government shareholder (N = 269); K-W - Kruskal-Wallis

Source: own work with Statistica 13.

As shown in Table 5, the results of the median test and the Kruskal-Wallis test conducted for the EMEA countries differ between GOV and NGOV companies. In the case of companies with a government shareholder, there is no reason to reject both hypotheses that the median values of the SOA coefficients are equal among the EMEA 
countries and that the distribution of the SOA coefficient is identical among the EMEA countries, regardless of the SOA computation method. In the case of companies without a government shareholder, at the $5 \%$ significance level, we reject the hypothesis that the median values of the SOA are equal among the EMEA countries when Larkin, Leary, \& Michaely's approach is employed. We also reject the hypothesis that the distribution of the SOA coefficient is identical among the EMEA countries, regardless of the SOA computation method used.

Furthermore, we determined whether the results of both approaches (Lintner's and Larkin, Leary, \& Michaely's approaches) differ among the EMEA countries (Table 6). To this end, we also employed the median and the Kruskal-Wallis rank test. The results of the median test are different depending on the SOA computation method, whereas those of the Kruskal-Wallis rank test remain comparable, regardless of the computation method.

Table 6. Results of the median test and the Kruskal-Wallis test for the SOA coefficient among EMEA countries - Lintner's approach vs. Larkin, Leary, \& Michaely's approach

\begin{tabular}{|c|c|c|c|c|}
\hline Method* & Median test statistic & p-value & K-W test statistic & p-value \\
\hline L & 12.7276 & 0.1216 & 18.5848 & 0.0172 \\
\hline LLM & 19.5895 & 0.0120 & 23.6091 & 0.0027 \\
\hline
\end{tabular}

* Explanations - compare Table 4

Source: own work with Statistica 13.

Overall, the results of the median test show that, assuming a 5\% significance level, the median values of the SOA coefficients are equal among the EMEA countries when Linter's model for computing the SOA is applied and are not equal when Larkin, Leary, \& Michaely's approach is used. According to the findings of the Kruskal-Wallis rank test, at the 5\% significance level, we reject the hypothesis that the distribution of the SOA coefficient is identical among the EMEA countries, regardless of the SOA computation method. 


\section{CONCLUSIONS}

In this study, we investigated the dividend patterns among companies listed on the stock exchanges of selected EMEA countries, namely, the Czech Republic, Egypt, Greece, Hungary, Poland, Qatar, the Russian Federation, South Africa, Turkey, and the United Arab Emirates.

The study addresses the issue of the differences in dividend payout ratios between companies with- and without state ownership. The obtained results suggest that companies with government presence in the shareholders' structure pay on average higher dividends. Thus, our results are consistent with those of Kowerski \& Wypych (2016). Our findings also coincide with those of Bena \& Hanousek (2008) and El-Ansary \& Gomaa (2012), which indicated that state-controlled companies pay the highest dividends among all other ownership types. This situation is due to, among others, their higher profitability and lower indebtedness compared with privately owned companies.

In this paper we also investigated the smoothing patterns of companies listed on the selected emerging stock markets. To this end, we employed two distinct methods of estimating the SOA coefficient, which reflects the speed of the dividend adjustment. The first method (Lintner's classical approach) brought us to the conclusion that companies in selected EMEA countries do not generally smooth dividends over time, which is exhibited by the relatively high levels of the SOA coefficient. On the contrary, the second method (Larkin, Leary, \& Michaely's approach) revealed moderately lower values of the SOA coefficient for eight out of the nine countries analysed (except Hungary). The obtained results from the second method proved that managers from the selected companies smooth dividends to some extent. Moreover, the mean values of the SOA in both approaches turned out to differ significantly. It is pertinent to note that in the majority of papers devoted to dividend smoothing only one method of computing the SOA coefficient is employed. Thus, our paper contributes to the existing literature by estimating the SOA coefficient on the basis of two distinct methods and by comparing the outcomes. However, in our paper we do not provide an explicit evidence that managers of the companies listed on emerging stock markets follow a stable dividend policy.

Eventually, we also addressed if the state presence in the ownership's structure affects the smoothing dividend behaviour. Our findings do 
not allow us to confirm that companies with state ownership smooth dividends more intensively than those without state ownership. The obtained SOA coefficients are high for the state-owned enterprises only in the second method (Larkin, Leary, \& Michaely, 2016), but the difference is not statistically significant. Our results contradict those of Gugler (2003), but are consistent with those of Jeong (2013), which concluded that ownership structure does not affect the SOA.

At the end, we would like to indicate the main limitations of the current study. First, we identified companies with state ownership, but did not consider the exact levels of the ownership stake as we used state ownership as a dummy variable. Second, agency theory could have been examined more accurately by including the concentration size of both state and institutional ownership.

Several issues should be considered in future research. The precise levels of the ownership's stake should be taken into account which would allow evaluating the impact of the particular shareholder on the company's dividend policy. Moreover, other potential determinants, apart from ownership structure, should be included in the analysis. Finally, panel data analysis is recommended to be applied in future research.

\section{ACKNOWLEDGMENTS}

The research was conducted and financed within the research grant (project number 2014/15/D/HS4/01220) funded by the National Science Centre, Poland.

Data collected from Thomson Reuters Eikon 4 according to Partnership Agreement between the University of Gdansk and the Thomson Reuters.

\section{REFERENCES}

Adaoglu, C. (2000). Instability in the Dividend Policy of the Istanbul Stock Exchange (ISE) Corporations: Evidence From an Emerging Market. Emerging Markets Review, 1(3), 252-270.

Aivazian, V., Booth, I., Cleary, S. (2003). Do Emerging Market Firms Follow Different Dividend Policies from U.S. Firms? Journal of Financial Research, 26(3), 371-387. 
Al-Ajmi, J. (2010). Modelling the Dividend Policy of Banks in Gulf Cooperation Council Countries. Applied Economics Letters, 17(14), 1423-1428.

Al-Najjar, B. (2009). Dividend Behaviour and Smoothing New Evidence from Jordanian Panel Data. Studies in Economics and Finance, 26(3), 182-197. Al-Najjar, B., \& Kilincarslan, E. (2017). Corporate Dividend Decisions and Dividend Smoothing: New Evidence from an Empirical Study of Turkish Firms. International Journal of Managerial Finance, 13(3), 304-331.

Al-Malkawi, H.A.N., Bhatti, M.I., \& Magableh, S.I. (2014). On the Dividend Smoothing, Signaling and the Global Financial Crisis. Economic Modelling, 42, 159-165.

Belomyttseva, O., \& Grinkevich, L. (2017). Dividend Policy of State-Owned Companies: Evidence from the Russian Federation. In: New Trends in Finance and Accounting (pp. 749-759). Cham: Springer.

Belousova, A.A., Gurianov, P.A., Melnichuk, A.V., Vinichenko, M.V., \& Duplij, E.V. (2016). Dividend Payments and Cross-country Differences in the Choice of Dividend. International Journal of Economics and Financial Issues, 6(S1), 46-51.

Bena, J., \& Hanousek, J. (2008). Rent Extraction by Large Shareholders: Evidence Using Dividend Policy in the Czech Republic. Finance a úvěr - Czech Journal of Economics and Finance, 58(3-4), 106-130.

Berezinets, I., Ilina, Y., \& Alekseeva, L. (2014). Ownership Structure and Dividend Policy: A Study of Russian Public Companies with Dual Class Shares. Working Paper, 5(E). St. Petersburg: Graduate School of Management, St. Petersburg State University.

Brav, A., Graham, J.R., Harvey, C.R., \& Michaely, R. (2005). Payout Policy in the 21st Century. Journal of Financial Economics, 77(3), 483-527.

El-Ansary, O., \& Gomaa, T. (2012). The Life Cycle Theory of Dividends: Evidence from Egypt. International Research Journal of Finance and Economics, 97, 72-80.

Eriotis, N., \& Vasiliou, D. (2011). Dividend Policy: An Empirical Analysis of the Greek Market. International Business \& Economics Research Journal (IBER), 3(3), 49-58.

Eriotis, N., Vasiliou, D., \& Zisis, V. (2007). A Birds Eye View of the Dividend Policy of the Banking Industry in Greece. International Research Journal of Finance and Economics, 11(11), 21-29.

Fama, E.F., \& Babiak, H. (1968). Dividend Policy: An Empirical Analysis. Journal of the American Statistical Association, 63(324), 1132-1161.

Gostkowska-Drzewicka, M., \& Majerowska, E. (2016). The Relevance of Dividend Smoothing in the Construction Companies Listed on the Warsaw Stock Exchange. Financial Sciences/Nauki o Finansach, 2(27), 9-22. 
Gugler, K. (2003). Corporate Governance, Dividend Payout Policy, and the Interrelation Between Dividends, R\&D, and Capital Investment. Journal of Banking \& Finance, 27(7), 1297-1321.

Hassan, M.K., Farhat, J., \& Al-Zubi, B. (2003). Dividend Signalling Hypothesis and Short-term Asset Concentration of Islamic Interest Free Banking. Islamic Economic Studies, 11(1), 1-30.

Heydari, S., Razeghi, S.F.M., \& Sharifi, A. (2015). Investigating the Relationship Between Institutional Ownership with Financial Policies and Performance of Listed Companies in Tehran Stock Exchange. Singaporean Journal of Business, Economics and Management Studies, 3(11), 18-30.

Ho, H. (2003). Dividend Policies in Australia and Japan. International Advances in Economic Research, 9(2), 91-100.

Ibrahim, M. (2016). Dividend Performance in the United Arab Emirates Banking Sector. International Journal of Finance \& Banking Studies, 5(6), 1-8.

Javakhadze, D., Ferris, S.P., \& Sen, N. (2014). An International Analysis of Dividend Smoothing. Journal of Corporate Finance, 29, 200-220.

Jensen, M.C., \& Meckling, W.H. (1976). Theory of the Firm: Managerial Behavior, Agency Costs and Ownership Structure. Journal of Financial Economics, 3(4), 305-360.

Jeong, J.H. (2013). Determinants of Dividend Smoothing in Emerging Market: The Case of Korea. Emerging Markets Review, 17, 76-88.

Khan, T. (2006). Company Dividends and Ownership Structure: Evidence from UK Panel Data. The Economic Journal, 116(510), 172-189.

Kowalewski, O., Stetsyuk, I., \& Talavera, O. (2007). Corporate Governance and Dividend Policy in Poland. Discussion Papers, 702, 1-22, German Institute for Economic Research.

Kowerski, M., \& Wypych, M. (2016). Ownership Structure and Dividend Strategy of Public Companies. Evidence from Poland. Barometr Regionalny. Analizy i prognozy, 4, 179-192.

La Porta, R., Lopez-de-Silanes, F., Shleifer, A., \& Vishny, R.W. (2000). Agency Problems and Dividend Policies Around the World. The Journal of Finance, 55(1), 1-33.

Larkin, Y., Leary, M.T., \& Michaely, R. (2016). Do Investors Value Dividend-Smoothing Stocks Differently? Management Science, published online September 29, 2016, http://dx.doi.org/10.1287/mnsc.2016.2551 [access: 27.06.2017].

Leary, M., \& Michaely, R. (2011). Determinants of Dividend Smoothing: Empirical Evidence. The Review of Financial Studies, 24(10), 3197-3249.

Leary, M.T., \& Michaely, R. (2008). Why do Firms Smooth Dividends. Johnson School Research Paper Series, August 11, retrieved from SSRN. 
Lintner, J. (1956). Distribution of Incomes of Corporations Among Dividends, Retained Earnings, and Taxes. The American Economic Review, 46(2), 97-113.

Marsh, T.A., \& Merton, R.C. (1987). Dividend Behavior for the Aggregate Stock Market. Journal of Business, 60(1), 1-40.

Maury, C.B., \& Pajuste, A. (2002). Controlling Shareholders, Agency Problems, and Dividend Policy in Finland. Liiketaloudellinen Aikakauskirja LTA, 1, 15-45.

Michaely, R., \& Roberts, M.R. (2011). Corporate Dividend Policies: Lessons From Private Firms. The Review of Financial Studies, 25(3), 711-746.

Miller, M.H., \& Modigliani, F. (1961). Dividend Policy, Growth, and the Valuation of Shares. The Journal of Business, 34(4), 411-433.

Mitton, T. (2004). Corporate Governance and Dividend Policy in Emerging Markets. Emerging Markets Review, 5(4), 409-426.

Obradovich, J., \& Gill, A. (2013). Corporate Governance, Institutional Ownership, and the Decision to Pay the Amount of Dividends: Evidence from USA. Faculty Publications and Presentations. Paper 26, http://digitalcommons. liberty.edu/busi_fac_pubs/26 [access: 27.06.2017].

Rangvid, J., Schmeling, M., \& Schrimpf, A. (2014). Dividend Predictability Around the World. Journal of Financial and Quantitative Analysis, 49(5-6), 1255-1277.

Shinozaki, S., \& Uchida, K. (2014). Ownership Structure, Tax Regime, and Dividend Smoothing: International Evidence. Asian Finance Association (ASFA) Conference Paper, retrieved from SSRN.

Shinozaki, S., \& Uchida, K. (2015). Ownership Structure and Dividend Smoothing: International Evidence. Working Paper Faculty of Economics, Kyushu University.

Shleifer, A., \& Vishny, R.W. (1997). A Survey of Corporate Governance. The Journal of Finance, 52(2), 737-783.

Short, H., Zhang, H., \& Keasey, K. (2002). The Link Between Dividend Policy and Institutional Ownership. Journal of Corporate Finance, 8(2), 105-122.

Wang, Xi, Manry, D., \& Wandler, S. (2011). The Impact of Government Ownership on Dividend Policy in China. Advances in Accounting, 27(2), 366-372.

World Development Indicators (2017). Retrieved from http://data.worldbank.org/ data-catalog/world-development-indicators [access: 27.06.2017]. 


\section{CZY PAŃSTWO JEST ZACHKANNE? WPKYW OBECNOŚCI PAŃSTWOWEGO AKCJONARIUSZA NA POZIOM I SZYBKOŚĆ WYPŁACANIA DYWIDENDY}

\section{Abstrakt}

Tło badań. Badanie koncentruje się wokół wzorców wypłacania dywidendy przez spółki notowane na giełdach papierów wartościowych wybranych krajów Europy, Bliskiego Wschodu i Afryki (EMEA), mianowicie: Czech, Egiptu, Węgier, Polski, Kataru, Federacji Rosyjskiej, Republiki Południowej Afryki, Turcji oraz Zjednoczonych Emiratów Arabskich.

Cele badań. Teoria agencji i rola struktury akcjonariatu w kształtowaniu polityki dywidendy sa przedmiotem licznych badań empirycznych. Celem niniejszego badania jest próba odpowiedzi na pytanie, czy występują różnice w poziomach współczynników wypłaty dywidendy pomiędzy spółkami z udziałem państwa w strukturze akcjonariatu i bez tego udziału. Ponadto celem badania jest ocena szybkości wygładzania dywidend przez spółki wybranych krajów EMEA, biorąc pod uwagę obecność w nich państwowego akcjonariusza.

Metodologia. W badaniu zastosowano metodę najmniejszych kwadratów do estymacji parametrów dwóch odrębnych równań odzwierciedlających szybkość wygładzania dywidendy. Dodatkowo do analizy statystycznej wykorzystano zestaw odpowiednich testów parametrycznych i nieparametrycznych.

Kluczowe wnioski. Wyniki badania wskazuja, iż obecność państwa w strukturze akcjonariatu spółki idzie w parze z wysokim poziomem współczynnika wypłaty dywidendy. Wyniki analizy zjawiska wygładzania dywidendy sa natomiast niejednoznaczne. Pomimo tego iż duża liczba badanych spółek wygładza dywidendy, przeciętny poziom współczynników dopasowania dywidendy do uzyskiwanych zysków (SOA) wśród wybranych krajów EMEA pozostaje relatywnie wysoki. Co więcej, poziom ten różni się w zależności od zastosowanej procedury badawczej (równania przyjętego do estymacji). Nie znaleziono natomiast istotnych różnic w przeciętnych poziomach SOA pomiędzy spółkami z udziałem państwa w strukturze akcjonariatu i bez tego udziału.

Słowa kluczowe: wygładzanie dywidendy, współczynnik wypłaty dywidendy, akcjonariusz państwowy, giełdowe rynki wschodzące, kraje regionu Europy, Bliskiego Wschodu i Afryki 